\title{
Innovation ecosystems articulation and shared value creation
}

\section{BRUNO ANICET BITTENCOURT ${ }^{12}$ PAOLA SCHMitT Figueiró ${ }^{3}$}

${ }^{1}$ Universidade federal do Rio Grande do Sul (UFrgS) / Programa de Pós-Graduação em Administração, Porto Alegre, RS - Brazil

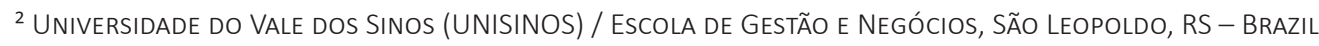

${ }^{3}$ Universidade Feevale / Programa de Pós-Graduação em Administração, Novo hamburgo, RS - BraziL

\begin{abstract}
The changes in the perception about the role of organizations reinforce the notion that creating value for society is as important as generating profit for shareholders. Against this backdrop, this study assumes that innovation ecosystems, because they are based on the interconnection and interrelation of a network of actors to generate innovation, have an important role in balancing profit generation and the creation of value for society. The research question: how can the articulation of an innovation ecosystem generate shared value for all those involved? led to a participatory action research exploring an initiative gathering a German multinational company located in the southern region of Brazil, a public school, a university, the local government, and the community. The initiative producing this interaction was called project "Arcos." It aimed to connect the company's managers and university and school students, who formed an innovation ecosystem to create shared value and address local social problems. The study presents a framework with the main benefits perceived by the network of actors, as well as propositions about innovation ecosystems and shared value creation.
\end{abstract}

Keywords: Ecosistema de innovación. Red de actores. Valor compartido.

\section{A criação de valor compartilhado com base em um ecossistema de inovação}

\section{Resumo}

Frente a uma mudança de percepção acerca do papel das organizações, tão importante quanto gerar lucro para os acionistas é gerar valor para a sociedade. Para tanto, parte-se do pressuposto de que a formação de um ecossistema de inovação, por intermédio da interconexão e inter-relação de uma rede de atores para gerar inovação, pode contribuir neste processo. Assim, propõe-se a seguinte questão: como a articulação de um ecossistema de inovação pode gerar valor compartilhado a todos os envolvidos? Desse modo, realizou-se uma pesquisaação participante no sul do Brasil, com base na interação entre uma empresa multinacional alemã, uma escola pública, uma universidade, o governo municipal e a comunidade local. O projeto que resultou desta interação denominou-se Arcos e teve como finalidade a resolução de um problema social por parte de gestores, universitários e alunos da escola, formando um ecossistema que permitiu a criação de valor compartilhado a todos os envolvidos. Como resultados têm-se um framework com os principais benefícios e proposições acerca da temática.

Palavras-chave: Ecossistema de inovação. Rede de atores. Valor compartilhado.

\section{La creación de valor compartido a partir de un ecosistema de innovación}

\section{Resumen}

Frente a un cambio de percepción acerca del papel de las organizaciones, tan importante como generar ganancias a los accionistas, es generar valor a la sociedad. Para ello, se parte del supuesto de que la formación de un ecosistema de innovación, a partir de la interconexión e interrelación de una red de actores para generar innovación, puede contribuir en este proceso. Así, se propone la siguiente cuestión: ¿cómo la articulación de un ecosistema de innovación puede generar valor compartido a todos los involucrados? Para ello, se realizó una investigación-acción participativa en el sur de Brasil, a partir de la interacción entre una empresa multinacional alemana, una escuela pública, una universidad, el gobierno municipal y la comunidad local. El proyecto que resultó de esta interacción se denominó Arcos y tuvo como finalidad la resolución de un problema social por parte de gestores, universitarios y alumnos de la escuela, formando un ecosistema que permitió la creación de valor compartido a todos los involucrados. Los resultados obtenidos fueron un marco de referencia con los principales beneficios percibidos por la red de actores y cuestionamientos acerca de la temática.

Palabras clave: Difusión de innovaciones. Innovación en servicios públicos. Difusión de innovaciones en servicios públicos. 


\section{INTRODUCTION}

Critical insight into the interconnection of environmental, social, and economic issues emphasizes the need to rethink patterns grounded in a system that is not balanced. Therefore, the central perspective of this study is based on rethinking behaviors within the organizations, considering the importance of the companies in the environment they are operating, as well as their capacity to generate shared value for a network that goes beyond the company's shareholders. This research recognizes that there is a shift in the field of innovation, from company-centered to network-centered innovation (NAMBISAN and SAWHNEY, 2011). However, for the company to be prepared for such a paradigm, it is essential that its managers and employees are motivated to face a very challenging process.

In this context, innovation ecosystems, i.e., the interconnection and interrelation of a network of actors (GOMES, FACIN, SALERNO et al., 2018) that interact to foster innovation (REINOLDS and UYGUN, 2017), may act as a stimulating environment for shared value creation (PORTER and KRAMER, 2011). The central premise of shared value is that the company's competitiveness and the health of the community are mutually dependent. The relation emphasized in this study, therefore, involves precisely the potential of an innovation ecosystem to createshared value through innovation.

As for the issue of forming an ecosystem, the participation and interaction of organizations such as universities, companies, governments, and society are crucial, stressing that the element 'society' is the one that characterizes the quadruple helix approach proposed by Carayannis and Campbell (2009). The research question guiding this study addresses the interaction among these actors, askinghow can the articulation of an innovation ecosystem generate shared value for all those involved?The aim is to analyze the process of shared value creation from the perspective of the actors involved in an innovation ecosystem.

The research adopted the participatory action research approach and observed a case in the South of Brazil. The case presents the interaction among a German multinational company, a public school, a university, the local government, and the community. The initiative was called project "Arcos," and gathered the company's managers, and university and school students, forming an ecosystem that allowed shared value creation and solving local social problems.

This article is structured in six sections, including this introduction. The next section presents the theoretical framework, focusing on innovation ecosystems and shared value creation. The third section presents the methodology, followed by the analysis based on the participatory action research. The fifth section introduces the contributions of the project "Arcos," and the sixth and last section presents the final considerations and suggestions for future research.

\section{THEORETICAL FRAMEWORK}

\section{Innovation ecosystems and shared value creation}

This section discusses the theoretical approach to innovation ecosystems and shared value creation. Based on a conceptual perspective, the intention is to show the ability of the connections in a network of actors to generate innovation, considering the actors' willingness to cooperate and the importance of interactions in the process of shared value creation. One of the central elements to understand and to interpret the empiricalpart of the research involves the steps in the process of developing an innovation ecosystem (analysis, project, deployment, execution, and conclusion). Thus, the study considers these phases to analyze the interrelationship between the network of actors and the developments of the project "Arcos" with emphasis on the shared value creation.

\section{Innovation ecosystems}

The ecosystem approach emphasizes the connections and dynamics of evolution, competition, predation, and mutualism among the actors, which are precepts of natural systems that resemble what happens in business environments (SHAW and ALLEN, 2016). The term "ecosystem" is originally found in biology. It was first associated with business activities by Moore (1993) but wasobserved more often from the decade of 2010 onwards, mainly related to entrepreneurship (ISENBERG, 2010; STAM, 2015) and innovation (AUTIO and THOMAS, 2014). 
Innovation ecosystems can be understood as open and dynamic business environments (RABELO and BERNUS, 2015), permeated by cyclical flows of tangible resources (e.g.,financial resources) and intangible resources (e.g.,information). In such ecosystems, a network of interconnected and interrelated actors (GOMES, FACIN, SALERNO et al., 2018) interact in a complex way, competing but also cooperating to foster innovation (REYNOLDS and UYGUN, 2017).

Innovation ecosystems count on elements such as infrastructure, regulations, financial capital, knowledge, ideas, the interface between actors, architecture principles (RABELO and BERNUS, 2015), companies, consumers, suppliers, and regulatory agents (GOMES, FACIN, SALERNO et al., 2018). Spigel (2017) adds to these elements: entrepreneurs, workers, investors, mentors, favorable governmental policies, universities, and other sources of innovative knowledge, as well as a culture that encourages risk-taking. Moreover, beyond these tangible and intangible elements, it is crucial to consider the processes that occur within innovation ecosystems.

Therefore, it is necessary to understand, from an evolutionary and dynamic perspective, how innovation ecosystems develop over time and adapt to the contexts (SPIGEL and HARRISON, 2018). A thriving innovation ecosystem is the result of a process of continuous evolution, that is usually long, complex, and slow (RABELO and BERNUS, 2015). The ecosystem's development may present different stages of maturity (GOMES, FACIN, SALERNO et al., 2018), and possibly these different stages influence innovation in different ways.

Few studies propose to describe how innovation ecosystems emergence and develop. For Rabelo and Bernus (2015), the steps in the process of forming innovation ecosystems are: analysis (the decision to create the ecosystem is made); project (the architecture of the ecosystem is defined); deployment (the phase of taking the necessary actions for its operation, such as recruitment of actors, publicizing the actions, and establishing the infrastructure conditions); execution (ecosystem management activities); and conclusion (the ecosystem undergoes a metamorphosis to survive and continue to develop, or it is discontinued.

Ecosystems derive from an exogenous process (RABELO and BERNUS, 2015). Therefore, it is possible to understand that, for the formation and sustenance of an innovation ecosystem, promoting the interaction among different actors, it is necessary for all the stakeholders to perceive value in the cluster. The next topic emphasizes the value creation that connects the stakeholders within the ecosystem.

\section{Creating Shared Value}

The shared value creation is a perspective introduced as a management model by Michael Porter and Mark Kramer $(2006,2011)$. The authors assume that, for the long-term success of the business, creating value for society is as important as generating profit for shareholders. Value generation is an evolved form of capitalism, understanding that increasing the purchasing power of the population is not enough to generate long-term growth. It is necessary to engage in people development and add value (PORTER and KRAMER, 2011). The authors assume that shared value can be responsible for the next great transformation of administrative thinking, considering that it is a distinct, powerful and transformative model embedded in the central purpose of corporations (PORTER and KRAMER, 2014).

In this sense, Hart and Prahalad (2002) affirm that multinational companies should look for globalization strategies through the lens of inclusive capitalism. In other words, it is a matter of prospering without harming the communities. But for this change in business to take place, leadership roles need to develop new knowledge and skills, such as: more significant understanding of social problems, a broader view of the impacts of social problems on the enterprise's value chain, and capacity to transpose the discussions throughout profit or non-profit spheres (PORTER and KRAMER, 2011).

Morais Neto, Neis, and Pereira (2016), studying the field of organizational environment, describe how the progressive growth of a multinational company can occur, based on the notion of creating shared value. According to the authors, this is a management model that connects concepts of productivity and competition to the commitment toward environmental and social demands. This perspective was validated by analyzing the multinational studied, taking into account the following elements - aligned to the perspective of Porter and Kramer (2006, 2011): (i) organization's core business and the positioning of each business unit; (ii) points of intersection between business units and social issues; (iii) social issues chosen for strategic intervention; and (iv) the existence of social dimensions for the value proposition. The company researched presented concrete 
actions related to all elements, a scenario that helps to strengthen the regional cluster where the firm is inserted, in Brazil (MORAIS NETO, NEIS and PEREIRA, 2016).

It should be noted that partnerships between companies and other institutions with projects that may aggregate and facilitate the execution of shared value strategies are fundamental for the success of the actions. Often, approximations are necessary in order to complement the skills and knowledge of the actors involved. On the one hand, there is a scenario with managers without a deeper understanding of social and environmental issues. On the other, practitioners working in the social sector, in general, have limited knowledge on administrative matters, little entrepreneurial attitude and vision of the opportunities to generate shared value (PORTER and KRAMER, 2011).

Considering the growing academic interest in creating shared value, Dembek, Singh, and Bhakoo (2016) performed a systematic analysis on the issue, offering a better ontological and epistemological comprehension. The authors realized that the approach of creating shared value was still considered vague, and there was a discrepancy between the approach's definition and operationalization. This evidence reinforced the need for empirical studies on creating shared value (DEMBEK, SINGH and BHAKOO, 2016). Given the above, the next section presents the conceptual model used as the basis for the analysis in the empiricalpart of the research.

\section{Innovation ecosystem and shared value: conceptual model}

As mentioned before, this study adopts the perspective of Morais Neto, Neis and Pereira (2016), who indicate the inclusion of shared value in organizations through a management model that connects concepts of productivity and competition to the commitment to environmental and social demands. This perspective implies that people development and adding value can stimulate the adoption of shared value in the organization's purpose.

The connection of shared value creation and the innovation ecosystem occurs as the interaction and cooperation in a network formed by different actors - in this case, coming from the company, university, society, and government foster the creation of value to all stakeholders. Following the perspective of Porter and Kramer (2011), this connection involves individuals who, through complementary understandings, can at the same time generate competitiveness and opportunities related to social and environmental values for the company. Figure 1 shows the conceptual model that demonstrates such relation.

Figure 1

Conceptual model of an innovation ecosystem based on shared value

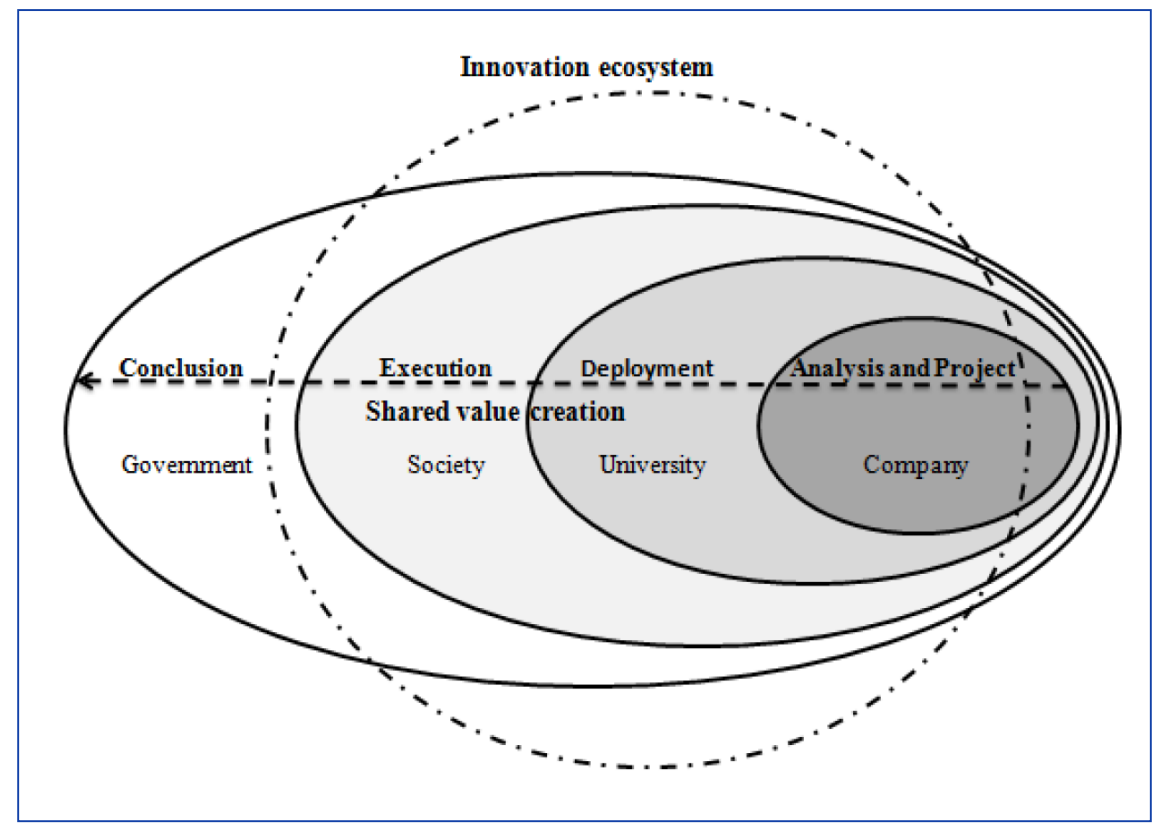

Source: Elaborated by the authors. 
The assumption is that the development and sustenance of an innovation ecosystem take place through the creation of shared value, that is, it is necessary that the different actors of the network perceive value in their participation in order to guarantee the ecosystem's growth and sustainability. In this case, this study adopts the quadruple helix approach, with the presence of a company, university, society, and government (CARAYANNIS and CAMPBELL, 2009).

This construction takes place through the steps brought by Rabelo and Bernus (2015): analysis, project, deployment, execution, and conclusion. In this perspective, the company assumes the role of pushing the movement forward, evidencing its capacity to generate not only financial but also social results (PORTER and KRAMER, 2011). In the sequence, the other actors are connected, cooperating, and generating innovation (GOMES, FACIN, SALERNO et al., 2018).

In short, the shift from a competition between individual companies to a competition between networks in the business arena has been discussed in the organizational literature for more than two decades (HATANI and MCGAUGHEY, 2013). However, in the last years, social welfare (PORTER and KRAMER, 2011) and the relationship between different actors such as university, society, and government (CARAYANNIS and CAMPBELL, 2009) have been identified as crucial factors for the generation of innovation and companies' survival. The next section presents the methodology adopted in this study to empirically understand these relationships.

\section{METHODOLOGY}

The method adopted was participatory action research, an approach that includes the implementation of a transformative action (KEMMIS and MCTAGGART, 2007). In this method, there is no separation between the subject and the object since the subjects researched are also subjects of the research and collaboratively participate in its construction. In addition, the approach unites theory and practice. It takes theory to the field, acting together with the subjects studied (BRANDÃO, 1984; THIOLLENT, 2003; KEMMIS and MCTAGGART, 2007). There is an educational and social transformation nature since all those involved in the research learn together. In addition, it is emancipatory, since the participants become aware of the situation, and can act more critically about their place in the environment (KEMMIS and MCTAGGART, 2007).

This type of research has a strong social commitment on the part of the researcher, who feels connected to the subjects studied and acts according to the values shared with them. Therefore, the researcher has the concern of making the study accessible to the public researched. Also, the researcher seeks to put their scientific curiosity in the service of a social benefit for the community (BRANDÃO, 1984).

The study followed the steps proposed by Kemmis and McTaggart (2007): (1) planning - collecting the necessary data and planning together the action to be taken; (2) acting and observing - the moment of action, which must be observed to generate data that will feed the reflections; and (3) reflecting - together with the subjects researched, this step involves reflection on the action taken, to understand what has emerged from the previous step and, if necessary, to provide inputs for planning a new action. It is important to briefly present the project "Arcos," object of this study, before introducing the procedures of data collection and analysis.

Project "Arcos" was designed and implemented by the authors of this research, in partnership with a German multinational company with operations in Brazil in the steel industry. The project counted on the initial participation of seven managers working in the company, 25 students from a public school near the company's facilities, and fifteen undergraduate students of the course of administration offered by a local private university. In a second moment, the local government and the community (parents of students and residents) joined the process. The purpose of the project was to form an ecosystem of local innovation with the engagement of different actors in the quadruple helix approach, as proposed by Carayannis and Campbell (2009): company, university, school, society, and government.

Project "Arcos" was designed and adapted into five steps, based on the work by Rabelo and Bernus (2015): (1) analysis; (2) project; (3) deployment; (4) execution and (5) conclusion. The first step consisted of identification (by the authors of this research in partnership with the German multinational company) of the need to create a local innovation ecosystem. After assessing this need, these same actors designed the project, focused on mobilizing players to solve a local problem. In the 
third step, the managers who held leadership positions in the company and the public school and university students were invited to join the group. The actors gathered in meetings and organized the project's schedule. The fourth step consisted of weekly meetings held to identify a local problem to be addressed and to develop and execute a possible solution. In the fifth and last step, the results were analyzed, generating reflections to guide the continuity of the project.

The weekly meetings held during the execution were conducted with the company's managers and the school students to identify the local problem to be addressed in the context of project "Arcos." University students engaged in the project in the same step, in the moment of proposing possible solutions. Finally, the local government and community also joined the project during execution. The meetings took place in different locations (school, company, university, and in the local park). The meetings occurred over six months. Data collection and research follow-up were conducted using the approach of participant observation since the researchers facilitated all the project meetings. The researchers used a field diary to examine the planning process and the materials elaborated during the meetings.

Finally, nine semi-structured interviews were carried out with the following actors: the director of human resources of the company; one of the managers that participated in the project; a professor of the undergraduate program in administration, responsible for the course the university students were attending when engaged in the project; a university student; the public school's principal and one school student; two residents in the local community; and one civil servant working for the local government. The questions of the interview script were elaborated based on the perception of the actors involved regarding the benefits obtained and the role played, considering that each actor collaborates and benefits from the process of creating shared value (PORTER and KRAMMER, 2011).

The data were analyzed and grouped following the steps proposed by Kemmis and McTaggart (2007) previously mentioned: (1) planning; (2) acting and observing; and (3) reflecting. The process of analysis considered the proposed objective, observing how the process of forming an innovation ecosystem can generate shared value. The analysis was guided by the conceptual model shown in Figure 1.

\section{ANALYSIS BASED ON PARTICIPATORY ACTION RESEARCH}

In this section, the results are presented and analyzed based on the steps mentioned in the methodology.

\section{Planning}

As observed before, the project "Arcos" was organized based on the steps outlined by Rabelo and Bernus (2015), with some adaptation. The steps used were: (1) analysis; (2) project; (3) deployment;(4) execution, and (5) conclusion.

In the step'analysis,' the researchers, together with the German multinational company, identified the need to form a local innovation ecosystem. The company triggered the process, presenting a demand for more effective social responsibility and involvement with its surroundings. In addition, the company was in a period of restructuring and sought to develop its leaders and generate innovation. On the part of the researchers, the conception of the project emerged as an opportunity to broaden, in an empirical way, the understanding around forming an innovation ecosystem and this ecosystem's contribution to creating value for all stakeholders.

In the step'project,' after the analysis of the needs, a methodological proposal was designed involving the study of learning practices that promote stakeholder engagement and generation of innovation. The approaches used were problem-based learning, design thinking, and theory $\mathrm{U}$. The project was then structured in three main phases: problem identification, the proposal of solutions, and execution of the proposal.

In the third step (deployment), the participants were invited. The profile of the company's employees to be invited was established together with the human resources department. The managers of the company's areas were chosen because of their capacity to impact more people within the organization. Seven managers were appointed as potential participants. Then, the university was approached through contact with a professor of the undergraduate program in administration of the largest higher education institution in the region. The intention was to verify the possibility of including a group of university students in the project. The professor was receptive, and 15 students of the course on social responsibility 
wereincluded in the project. For the professor, the project was an opportunity to teach elements of the course in a practical and contextualized way.

The next actors approached were the students of the local public school, located next to the company's facilities. In the design of the project, the school would be a representative of the link with the community, since the residents are somehow involved in the school's activities. Another element that led to the school's engagement was the fact that several of the company's employees' children studied there. Also, mixing the vision of adults, children, and young people would give potential to the project. Thus, the school's administration appointed 25 youngsters to participate in the initiative, aging from 10 to 15 years old.

The project schedule was structured with the participation of the company's human resources department, the school's administration, and the professor of the university - the actors engaged in weekly meetings lasting three hours each. In the first meetings, only the company's managers and the school students participated, due to time availability. During the activity of proposing solutions, the university students participated, contributing to a collective construction. After designing the proposal, the local government was contacted, in order to assist in the execution of the solution proposed.

Following the steps of Rabelo and Bernus (2015), aligned with the contributions byKemmis and McTaggart (2007), theexecution and conclusion steps are described below.

\section{Acting and observing}

The first meetings were structured with a focus on self-knowledge, team building, and the identification of a collective goal. In the first three meetings, company managers and school and university students did not know each other. The first activity with managers focused on listening, identifying the purpose of the individuals, and stimulating exchange among colleagues. The group then had the opportunity to learn about new business models and global changes for an era of collaboration and social responsibility.

After these first activities, the weekly meetings (at school or in the company) gathering managers and the school students started. The meetings were an opportunity for the actors to experience each other's routine. During these sessions, the actors were able to get to know each other, interact, and explore their relations with the neighborhood they were all connected to. Subsequent meetings were marked by brainstorming around possible problems in the region, and by identifying ways to understand these problems more deeply.

The group decided to conduct exploratory research with the residents in the community, in order to assess the most prominent local problems. Both managers and school students were involved in the elaboration and application of an instrument to explore the perceptions of the residents regarding the local problems. The group interviewed 103 people, who answered ten questions about their relationship with the community and their opinion about the context they were living in, exposing positive or negative aspects and things they wish to see in the region. The results of these interviews were presented to the university students who were engaged in contributingproposing solutions to the problems identified and to assist in the construction of a collective project.

The meetings that followed brought together the three publics: corporate managers, school students, and university students. The three groups came up with the same problem: the revitalization of a park near the company and the school. The argument was that, when solving this problem, other issues mentioned in the interviews would be tackled indirectly, such as public safety, income generation, leisure spaces, and community self-esteem. After much interaction and debate, it was concluded that the solution to this problem would be the reform and occupation of the park, organizing community events. The idea was to prepare an event with cultural activities, sports, food, and activities related to entrepreneurship. The design of this solution was prepared collaboratively and organically. The participants mapped possible partner initiatives that would contribute to the solution proposed.

The students at the school presented the proposal to their colleagues and involved parents and teachers in the activities. The same happened with the university students, who brought companies and volunteers to contribute to organizing the event. In the company, the mobilization was intense. The managers presented the project to the employees and other stakeholders, who became actively involved in the initiative. This mobilization reached the city administration and local civil servants, such as those responsible for managing the park. The mayor and several civil servants attended meetings, expressing their support, and validated the group's proposal. 
Other meetings held afterward focused on planning actions, practices, and control. The students met weekly with the managers and exchanged information online with the university students. With the support of a network of partners, it was possible to carry out a revitalization of the park and publicize the action in several channels, which helped to increase mobilization. The event involved approximately 500 people and featured musical and artistic attractions, sports tournaments, play areas for children, food court, handicraft fairs, and exhibitions of local businesses. All stakeholder had clear responsibilities and, in order to avoid excessive group segmentation, they worked in teams and collective alignment in order to value this collective learning process.

Given the success of the event planned by the group, the next challenge wasto continue the project. Thus, there were two more meetings to evaluate the positive and negative points, collect feedback of the event, and celebrate the achievements of the group.

\section{Reflecting}

The research examined the benefits and the role played by the participants of the projectto reflect on the process of forming a local ecosystem and creating shared value. This part of the study relied on interviews conducted with nine representatives of the different groups involved, as detailed in the methodology. The interview focused on the role of each actor, their involvement with the project, and the perceived individual and collective benefits.

"An analysis of each of the actors allows inferring that the company was the actor pushing project "Arcos." The firm was committed by encouraging the involvement of its managers, providing financial resources to acquire materials and supply other possible demands, and taking the risk of developing an innovative project. It represents, therefore, the cyclical flows of tangible (e.g., financial resources), and intangible resources (e.g., information), which, according to Gomes, Facin, Salerno, et al. (2018), are present in the interconnection of a network of actors. According to the human resources manager, the company was looking for a more assertive and meaningful way to develop leadership and found in this proposal a practical way to leverage leadership skills and, at the same time, to promote community benefits. It was a unique and impressive experience," said one of the participating managers. The interviewee also mentioned that the project took him totally out of his comfort zone, generating learning beyond his professional life. "It is much more difficult to lead a group of children and young people than a group of workers," said the manager, considering the difficulties of adapting to the scenario posed by the project. The group reported that during the process, employees from different sectors became closer, establishing stronger relations with the community. The atmosphere around the project also generated positive publicity for the company, evidence that the relationship was mutually beneficial.

As for the public school, the principal appointed 25 students aging from 10 to 15 years old to participate in the initiative, with the condition that the students would not be requested to miss their regular classes. The school also offered space to host meetings. The school's principal mentioned that the experience promoted several benefits. In her interview, the principal pointed out that the students were able to access different experiences that were not offered in the regular school activities. She added that the relationship with the other actors participating in the project made it possible for young people to gain visibility. In the words of a school student interviewed: "It was cool, we managed to change the park!" The feeling of pride was also present in the speech of a parent (and resident) interviewee "[...] there are plenty of problems. Thus, if these kids get to know how to address them from an early age, we will have a better world."

This theoretical-practical connection is one of the motivations for the university professor that facilitated the participation of the undergraduate students in the initiative. According to her, the contextualization of teaching allows students to easily assimilate learning. For the professor, the initiative was extremely beneficial: "My students were offered to live the content we studied in class, being exposed to the community's real problems. Certainly, they will be more prepared for the labor market after this experience." "We managed to assist more in the communication part of the project, as well as to identify activities to be conducted during the event [...] I had never imagined working with children and experienced managers together, it was a unique opportunity!"said one of the university students, who also highlighted teamwork and collaboration as main points for the success of the project.

The local community participated in different actions, from the identification of the problem to the activities performed in the event at the park. "We cannot wait for someone to solve the problems, we have to do it ourselves," said a resident interviewed. The resident also highlighted the fact that the project brought the feeling that it is possible for the residents to act to improve 
their neighborhood. The discourse of the residents showed the community revitalization as agreat benefit to all. "The park had not had so much life for some time," said one resident who took advantage of the event to exhibit her handicrafts.

Finally, when the city council learned about the initiative, it also volunteered to participate. The local government action involved the validation of the proposals, the availability of the staff responsible for the park's management and public environment, and they participated by publicizing the activity. As a return, the municipality observed that the community is more mature and engaged with local problem-solving. The local public administration managed to establish a closer relationship with the people and organizations involved, also enjoying the benefits of the visibility brought by project "Arcos." "It is exciting to see so many people gathered to improve a common space," said a civil servant interviewed.

In short, it is possible to affirm that during the process of interconnection and interrelationship of this network, the actors identified their role and contributed according to their competence. It is also worth mentioning that the different actors of the ecosystem perceived benefits with this articulation and collective construction. Thus, it can be inferred that the initiative allowed shared value creation. The nexttopic discusses the contributions of project "Arcos" and its developments.

\section{From the ecosystem to value generation: contributions of project "arcos"}

Following the conceptual model proposed for this research, it was possible to observe that the project, as an initiative forming an innovation ecosystem (RABELO and BERNUS, 2015), resulted in both collective and individual benefits for all stakeholder. It was clear the cooperation among the groups to foster innovation (REYNOLDS and UYGUN, 2017), creating shared value for the community, in line with Porter and Krammer's (2011) perspective.

Among the innovations generated, it is worth highlighting the opportunity offered for school and university students to learn curricular contents at the same time as gaining social-emotional competencies. Along the same lines, the process of leadership development within the company stood out, since the project allowed managers to use different tools and develop various behavioral skills when acting in practical tasks. In addition, the company performed a new model of social responsibility, focused on local development rather than welfare.

For the government, a new form of partnership was established, with a relationship centered on the society as a whole, extrapolating the regular public-private dynamic. As for the residents and small businesses, the initiative created a market opportunity, since the businesses could offer their products in an environment not yet explored. The project evidenced a value common to all stakeholders: the community engagement and strengthening, which is a structuring action for future innovations.

Thus, considering that the innovation ecosystem is the result of a dynamic and continuous evolution process (RABELO and BERNUS, 2015), Figure 2 shows the main benefits perceived by the actors participating in the ecosystem analyzed. 
Figure 2

Ecosystem of project "Arcos"

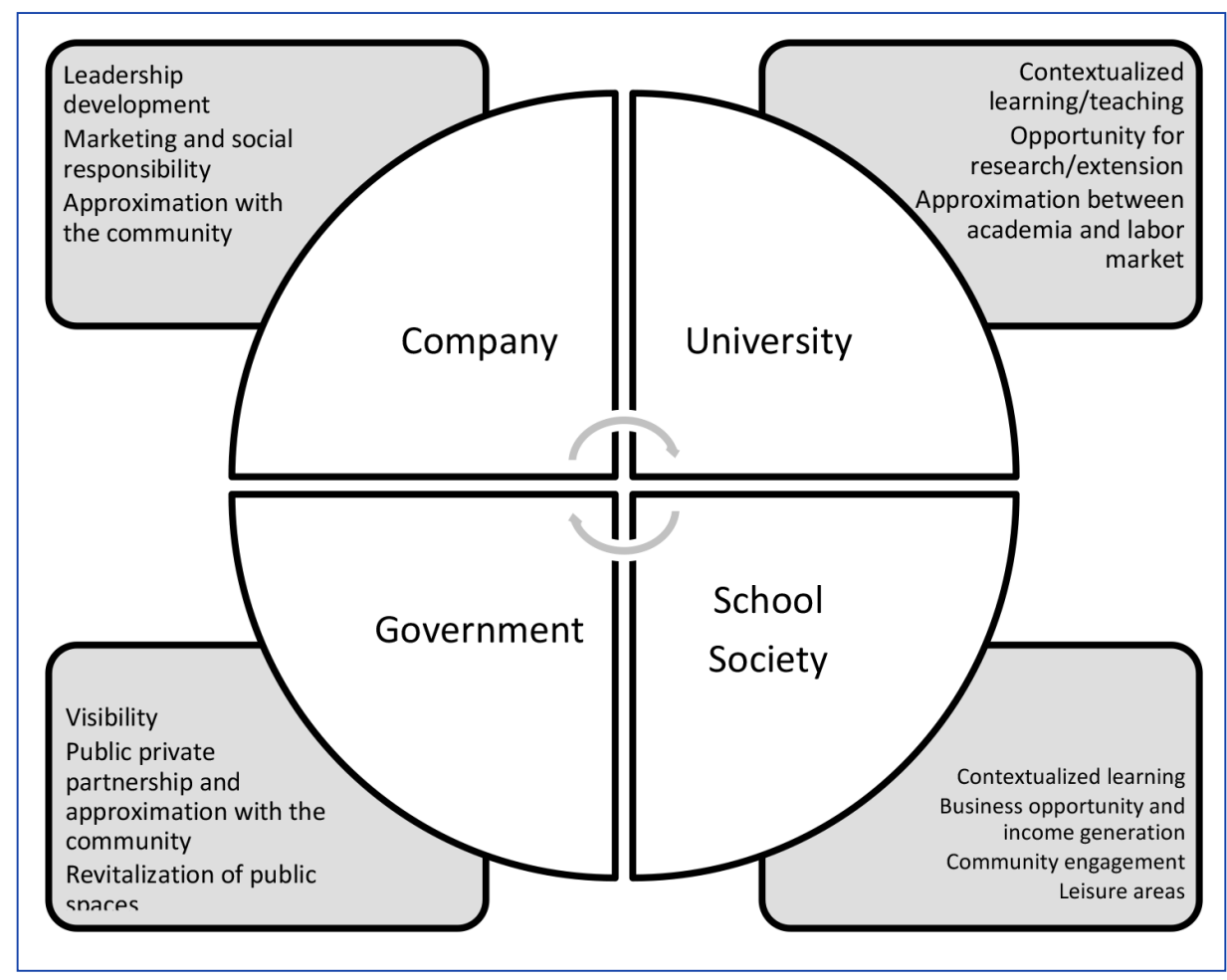

Source: Elaborated by the authors.

Based on the relations among the conceptual elements present in Figure 1, forming an innovation ecosystem from the project "Arcos," and on the benefits generated for the actors involved in the ecosystem (Figure 2), the research drafts three propositions, detailed in this section.

First, it was possible to identify the interconnection and interrelation of the network of actors (GOMES, FACIN, SALERNO et al., 2018). They interact in a complex way to foster innovation (REYNOLDS and UYGUN, 2017), indicating the formation of an ecosystem. In addition, it was verified the existence of social dimensions favoring value proposition (MORAIS NETO, NEIS and PEREIRA, 2016), as well as activities of people development aiming at adding value (PORTER and KRAMER, 2011), which are premises for creating shared value. Thus, it can be inferred that the experience studied indicates that an ecosystem of articulated innovation creates value for the different actors involved.

The innovation ecosystem presented contemplates the quadruple helix approach (CARAYANNIS and CAMPBELL, 2009), and it is not focused on business, but on creating social value. The benefits generated with the emerged innovation contributed to improving the environment where the actors live, particularly by promoting community engagement and revitalization of the public spaces of interaction. Therefore, the first proposition is that the efforts to create shared value consolidate the formation of an innovation ecosystem (Proposition 1).

The participation of different actors was essential for the development of the ecosystem and to generate innovation. Each of them contributed with skills at a particular step, as evidenced in Figure 1. The company was the actor that started the process, responsible for investing human and financial resources to carry out the analysis and the project itself. The university assisted in the initiative's deployment, offering technical knowledge and articulating to connect the actors forming the ecosystem. The society, represented by the school and the local community, played a fundamental role, being responsible for engaging people in the execution of the project. Finally, the government's involvement legitimized and validated the process, concluding the project. Such contributions are shown in Figure 3, which represents a spiral viewed from above. In addition, it is possible to observe that such contributions have emerged with the evidence listed in Figure 2. 
Figure 3

\section{Contributions of actors for the consolidation of the innovation ecosystem}

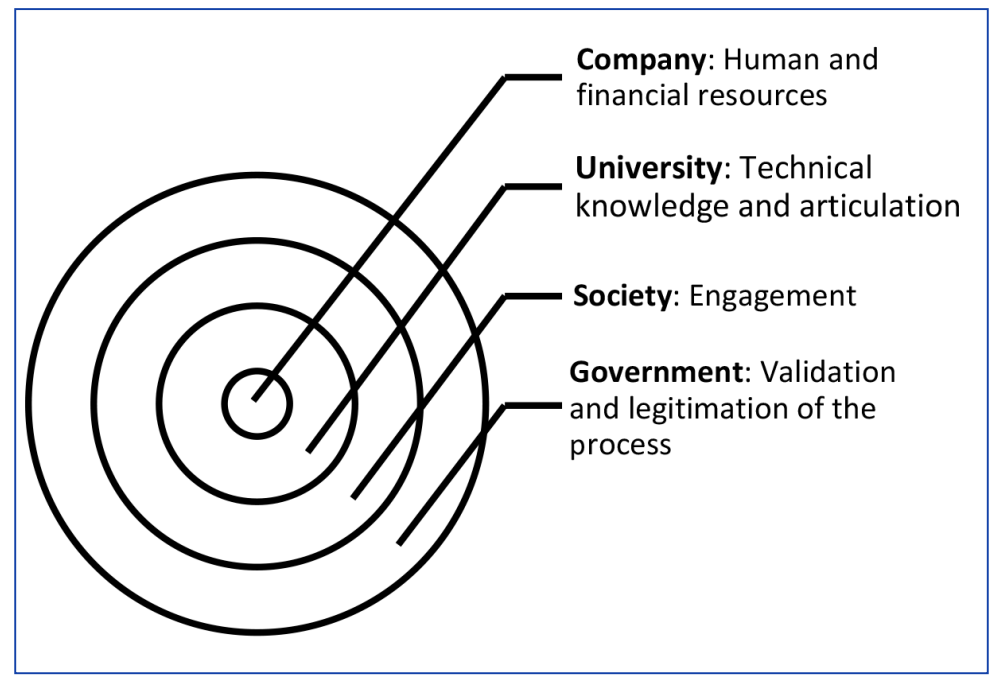

Source: Elaborated by the authors.

It is possible to say that the participation of actors in these four dimensions has enhanced the value created by the innovation ecosystem. Each actor played a fundamental role in the development of the ecosystem, and their participation increased the benefits generated. Thus, the second proposition is that the innovation generated by the ecosystem is proportional to the heterogeneity of its actors (Proposition 2).

Finally, the development of the project "Arcos" and the benefits perceived by its actors (Figure 2) led to understand these benefits at different levels, classified as micro, meso, and macro. The micro level is related to personal benefits; the meso level reflects organizational benefits; and the macro refers to local/community benefits. Box 1 shows the benefits and levels observed.

Box 1

Level of benefits

\begin{tabular}{|l|l|l|l|}
\hline Company & \multicolumn{1}{|c|}{ Level Micro } & \multicolumn{1}{|c|}{ Level Meso } & \multicolumn{1}{c|}{ Level Macro } \\
\hline University & $\begin{array}{l}\text { Leadership development } \\
\text { teaching }\end{array}$ & $\begin{array}{l}\text { Marketing and social } \\
\text { responsibility }\end{array}$ & $\begin{array}{l}\text { Approximation between } \\
\text { academy and labor market }\end{array}$ \\
\hline School / Society & $\begin{array}{l}\text { Contextualized learning/ } \\
\text { teaching; Business opportunity } \\
\text { and income generation }\end{array}$ & $\begin{array}{l}\text { Engagement of the school } \\
\text { community }\end{array}$ & Leisure areas \\
\hline Government & Visibility & $\begin{array}{l}\text { Public-private partnership and } \\
\text { community approximation }\end{array}$ & Revitalization of public spaces \\
\hline
\end{tabular}

Source: Elaborated by the authors.

There is an explicit relation between Figure 3 and Box 1. For the company, the micro and macro levels are provided through human resources, while the meso level is linked to the financial resource. For the university, all levels are directly related to the technical knowledge and ability to articulate connections in the environment. Regarding the school and society, engagement becomes one of the main drivers of the benefits generated at all three levels. Finally, the government played an important role in legitimizing the process. Starting from the macro level, the government demonstrated interest and granted permission for the revitalization of the public space, which generated a meso-level partnership and consequent visibility at the micro level. 
Thus, the generation of benefits at different levels may be considered as a stimulating factor for the engagement of actors and value creation in innovation ecosystems. Thus, the third proposition is that creating shared value in an ecosystem is related to the benefits generated at micro, meso, and macro levels for each actor (Proposition 3).

The propositions built on the reflections over the empirical case studied in this research intend to inspire theoretical and practical discussions and further contributions. The next and final section presents the research's conclusions lessons learned.

\section{FINAL CONSIDERATIONS}

Project "Arcos" was an organic process, centered on the value generation through the interconnection and interrelationship of a network of actors. The main objective of the research was to analyze how the interaction in an innovation ecosystem formed by university, company, government, and society can create shared value. It is important to mention that there is no empirical research adopting the same format as presented here, connecting different organizations as observed in project "Arcos," as well as using the research method and the same combination of theoretical approaches.

The process of forming the innovation ecosystem was based on the steps developed by Rabelo and Bernus (2015): analysis, project, deployment, execution, and conclusion. The conceptual model adopted the notion that shared value creation is connected to the innovation ecosystem as an alternative for the formation and sustenance of such agglomerations.

The analysis showed the importance of defining clearly the roles of each participant since the beginning of the initiative. In the experience studied, this measure helped to focus on the proposed objectives. Regarding the interaction between the actors, greater stimulus and support was needed for planning and publicizing information among the stakeholders, making better use of the available communication channels. Finally, it was observed that internal communication could have been better explored. Communication deficiencies have occurred, for example, between managers and university students, and with the parents of the students in the school. It was clear that the parents needed to understand what the project was providing for their children, because some expressed concern, fearing that the initiative was not constructive in the context of the children's education.

Given this, three propositions emerged as theoretical contributions. The first proposition concerns the fact that the search for creating shared value consolidates the formation of an innovation ecosystem. The essence of creating shared value, which includes the participation of society in the network of organizational relationships and people development (PORTER and KRAMMER, 2006, 2011), was crucial in forming the innovation ecosystem. The engagement of the company's leadership, in this case, was particularly important to help these actors to understand the impacts of social problems in the company's value chain (PORTER and KRAMER, 2011; MORAIS NETO, NEIS and PEREIRA, 2016). As the different actors approached to bring benefits to the community, an open and dynamic business environment was formed (RABELO and BERNUS, 2015). The environment fostered innovation, mainly through the sharing of knowledge and ideas.

Therefore, it was necessary to understand the value generated for the different audiences in order to guarantee the formation and sustainability of an innovation network. Thus, the second proposition indicates that the innovation generated by the ecosystem is proportional to the heterogeneity of its actors. The theoretical contribution, therefore, revolves around the importance of interconnection and interrelation (GOMES, FACIN, SALERNO et al., 2018), as well as the cooperation among those involved in fostering innovation (REYNOLDS and UYGUN, 2017). This reinforces that, corroborating the literature, the connection between different knowledge and competencies of an ecosystem contributes to an effective opportunity to generate innovation.

The third proposition relates to the creation of shared value in an ecosystem to the benefits generated at micro, meso, and macro levels for each of the actors. This proposition shows the need to think ofinstitutions in a broader way, including the impact they have on people and the environment. This proposition contributes notably to the theoretical perspective that points to the understanding of how innovation ecosystems develop and adapt to new contexts(SPIGEL and HARRISON, 2018), considering that new projects and new contexts demand different connections and, consequently, bring different results for each level of engagement. It is necessary, therefore, to identify the value perceived by and generated for each actor, considering the use of approximations to complement the actors' skills and knowledge (PORTER and KRAMER, 2011). 
In general, the project "Arcos" came about with a proposition of forming an innovation ecosystem in which there is the creation of shared value, i.e., generation of benefits to all stakeholders. Such an innovative proposition is inspiring in the current time when there is an economical, political, and social crisis at the national level in Brazil. The notion of a company that assumes co-responsibility in transforming the region in which it operates (principle of creating shared value) through participatory processes, is an alternative to promote the emergence and sustainability of innovation ecosystems, a theme still little approached in the literature (RABELO and BERNUS, 2015).

This work contributes to the literature on ecosystems and shared value creation, seeking to understand the construction of a network of innovation and the values it generates. In this way, the research brings an approximation of the existing theoretical approaches to the practice, as well as using a method in which the researcher is directly inserted in the field research. It was possible to rapidly observe the social change and the adoption of new values in the region, as a result of the interactions and exchanges that led to a collaborative proposal to address local problems. In addition to the concrete results, the experience showed an increasing awareness about the individuals' responsibility for the environment and their role as change makers, capable of inspiring and involving more people and organizations.

This research offers a relevant contribution to decision making in the public and private spheres. It offersa reflection on the importance of the articulation between different actors, and the project "Arcos" is an example of how to stimulate other actions that provide shared value creation. The participatory action research provides a direction for the planning and the accomplishment of projects aligned to the perspective presented in this article.

The lack of time to execute the research may be pointed out as the most critical limitation of the study. It was not possible to explore the project's medium and long-term results. A suggestion for future research would be to expand the research to other contexts, comparing different scenarios and groups of actors involved. Another suggestion is to study the process of articulation and the role of an actor coordinating the emergence and formation of innovation ecosystems. Finally, future research could explore elements such as the concept of the social innovation ecosystem, the links between shared value creation and public policies, and the relationship between forming innovation ecosystems and dependence on multinational companies. 


\section{REFERENCES}

AUTIO, E.; THOMAS, L. Innovation ecosystems:Implications for Innovation Management?In: DODGSON, M.; GANN, D. M.; PHILLIPS, N. (Eds.). The Oxford handbook of innovation management.London: The Oxford Handbookof Innovation Management, 2014. p. 204-228.

BRANDÃO, C. R. Repensando a pesquisaparticipante. São Paulo: Brasiliense, 1984.

CARAYANNIS, E. G., CAMPBELL, D. F. J. “Mode 3" and "Quadruple Helix": toward a 21st century fractal innovation ecosystem. International Journal of Technology Management, v. 46, n. 3/4, p. 201, 2009.

DEMBEK, K.; SINGH, P.; BHAKOO, V. Literature review of shared value: a theoretical conceptor a management buzzword? Journal of Business Ethics, v. 137, p. 231-267, 2016.

GOMES, L. A. de V. et al. Unpacking the innovation ecosystem construct: evolution, gaps and trends. Technological Forecasting and Social Change, v. 136, p. 30-48, 2018. Available at: <http://dx.doi. org/10.1016/j.techfore.2016.11.009>. Accessed on: June 08, 2019.

HART, S.; PRAHALAD, C. K. The fortune at the bottom of the pyramid. Strategy Business, v. 26, p. 54-67, 2002.

HATANI, F.; MCGAUGHEY, S. L. Network Cohesion in Global Expansion: An Evolutionary View. Journal of World Business, v. 48, n. 4, p. 455465, 2013.

ISENBERG, D. J. How to start an entrepreneurial revolution. Harvard business review, v. 88, n. 6, p. 40-50, 2010.

KEMMIS, S.; MCTAGGART, R. Participatory Action Research. In: DENZIN, N. K.; LINCOLN, Y. Handbook of qualitative research. 3. ed. London: Sage, 2007.

MOORE, J. F. Predators and prey: a new ecology of competition. Harvard Business Review, v. 71, n. 3, p. 75-83, 1993.

MORAIS NETO, S.; NEIS, D.; PEREIRA, M. F. O processo de criação de valor compartilhado. Revista de Administração FACES Journal, Belo Horizonte, v. 14, n. 4, p. 148-166, 2015.
NAMBISAN, S.; SAWHNEY, M. Orchestration processes in networkcentric innovation: evidence from the field. Academy of Management Perspectives, v. 25, n. 3, 2011.

PORTER, M. E.; KRAMER, M.R. Strategy and society: the link between competitive advantage and corporate social responsibility. Harvard Business Review, v. 84, n. 12, p. 78-92, 2006.

PORTER, M. E.; KRAMER, M. R. A response to Andrew Crane et al.'s article by Michael E. Porter and Mark R. Kramer. California Management Review, v. 56, n. 2, p.149-151, 2014.

PORTER, M. E.; KRAMER, M. R. Criação de Valor Compartilhado. 2011. Available at: <http://www.hbrbr.com.br/materia/criacao-devalor-compartilhado>. Accessed on: Jan. 28, 2016.

RABELO, R. J.; BERNUS, P. A holistic model of building innovation ecosystems. IFAC-PapersOnLine, v. 48, n. 3, p. 2250-2257, 2015.

REYNOLDS, E. B.; UYGUN, Y. Strengthening advanced manufacturing innovation ecosystems: The case of Massachusetts. Technological Forecasting and Social Change, v. 136, p. 178-191, Nov. 2018. Available at: <http://dx.doi.org/10.1016/j.techfore.2017.06.003>. Accessed on: June 08, 2019.

SHAW, D. R.; ALLEN, T. Studying innovation ecosystems using ecology theory. Technological Forecasting and Social Change, v. 136, p. 1-362, Nov. 2018.

SPIGEL, B. The relational organization of entrepreneurial ecosystems. Entrepreneurship Theory and Practice, v. 41, n. 1, p. 49-72, 2017.

SPIGEL, B.; HARRISON, R. Toward a process theory of entrepreneurial ecosystems. Strategic Entrepreneurship Journal, v. 12, n. 1, p. 151$168,2018$.

STAM, E. Entrepreneurial ecosystems and regional policy: a sympathetic critique. European Planning Studies, v. 23, n. 9, p. 1759-1769, 2015.

THIOLLENT, M. Metodologia da Pesquisa-Ação. São Paulo: Cortez, 2003.

Bruno Anicet Bittencourt

ORCID: https://orcid.org/0000-0002-6499-3588

PhD Student and Master in administration from the Federal University of Rio Grande do Sul (UFRGS); Professor at the University of Vale dos Sinos (UNISINOS), São Leopoldo - RS, Brazil. E-mail:banicet@unisinos.br

Paola Schmitt Figueiró

ORCID: https://orcid.org/0000-0002-5160-9831

PhD in administration from the Federal University of Rio Grande do Sul (UFRGS); Professor at the Feevale University, Novo Hamburgo - RS, Brazil. E-mail: paolafigueiro@feevale.br 